\title{
Lembrar é preciso: as conquistas portuguesas revisitadas por exemplares da imprensa colonial elaborada em Portugal e Moçambique (1922 - 1937).
}

\author{
Remembering is necessary: the Portuguese conquests revisited by the \\ colonial press created in Portugal and Mozambique (1922 - 1937).
}

\section{Leandro Antonio Guirro**}

RESUMO

A preservação de uma vitória pode perder-se rapidamente se não for rememorada e idealizada para as gerações futuras. Surge, então, a necessidade de se criar narrativas que mantenham vivas as glórias e respaldem as ações presentes. Da mesma forma, os que foram derrotados podem elaborar novas estratégias de enfrentamento para manterem-se ativos diante de um cenário no qual não são mais considerados atores principais, mesmo que ainda sejam imprescindíveis para o desenrolar da trama histórica. Grosso modo, foi assim que se desenvolveram as relações entre Portugal e Moçambique colonial. Portanto, o artigo objetiva refletir sobre o surgimento e atuação de alguns periódicos que fizeram do colonialismo teor de discussão em ambos os lados e levantaram a problemática da tradição imperialista portuguesa para seus leitores. Para tal, vale-se da proposta analítica de averiguações "intra-jornal" e "interjornais", defendidas por Zicman, e das orientações de Capelato e Prado, segundo as quais os impressos são concebidos como instrumentos capazes de intervir e manipular interesses na sociedade. Conjectura-se, ao final, que a rememoração do passado conquistador lusitano esteve ligada à busca de legitimidade dos autores dentro da sistemática colonial.

Palavras-chave: Imperialismo. Tradição. Legitimação. Assimilação. Imprensa.

ABSTRACT

The preservation of a victory can be lost very quickly if it is not remembered and idealized to future generations. That is why it is essential to create narratives which uphold the glories and resort to present actions. Similarly, the defeated ones can elaborate on new coping strategies so as to keep themselvesactive

\footnotetext{
* O presente trabalho foi realizado com apoio do CNPq, Conselho Nacional de Desenvolvimento Científico e Tecnológico Brasil.

${ }^{* *}$ Mestre em História - Doutorando - Programa de Pós-graduação em História - Faculdade de Ciências e Letras de Assis UNESP.
} 
before a scenario in which they are not considered leading actors any more, even if they are crucial for the development of the historical plot. Basically, the relationships between Portugal and Mozambique were developed in this way. Thus, this article aims to reflect on the appearance and actions of some periodicals which made the colonialism subject of discussion on both sides and arose the problems of Portuguese imperialist tradition to their readers. As a result, this article is based on the analytical proposal of investigations "intra-newspaper" and "inter-newspapers", defended by Zicman, and based on Capelato's and Prado's orientations, which state that newspapers are conceived as a tool capable of interfering in a society and manipulating interests. We conclude, therefore, that the recollection of Portugal's dominating past was linked to the search for the authors' legitimacy in the colonial system.

Keyword: Imperialism. Tradition. Legitimation. Assimilation. Press.

\section{Uma breve análise do periodismo colonial em Lisboa e Lourenço Marques}

Zicman (1981, p. 98) foi incisiva ao defender o princípio de que a imprensa opera continuamente no campo político-ideológico, tornando-se necessário que as pesquisas embasadas na interpretação de jornais e outros tipos de periódicos necessariamente delineiem as características essenciais dos órgãos consultados. Semelhantemente, Braga (2012, p. 298) atestou que se compreende o noticiário impresso através do entendimento do seu contexto, seu processo de criação, suas expectativas e recepção. Mesmo ressaltando-se os pormenores de cada material, é também oportuno indagá-los sob um prisma globalizante. Sendo assim, algumas pontuações sobre o expansionismo europeu desencadeado entre final do século XIX e início do XX tonam-se importantes para o estudo do que foi escrito tanto em Portugal quanto em Moçambique.

Cabaço (2009, p. 34) lembrou que a Conferência de Berlim, um dos símbolos máximos da expansão imperialista, constituiu "pedra miliar" no estabelecimento do poder colonial que passou a caracterizar a ocupação africana no século XX. As estatísticas levantadas por Boahen (2010, p. 1) demonstram o referido acima: até 1880 , cerca de $80 \%$ do território africano era governado pelos próprios nativos, sendo que, em 1914, somente Etiópia e Libéria não faziam parte do domínio europeu no continente.

A maioria das terras ficou em mãos inglesas e francesas, principais expoentes do capitalismo industrial e solidez governamental. As demais "fatias" ficaram sob controle belga, italiano, alemão, espanhol e português (HERNANDEZ, 2008, p. 68). Por meio de um projeto conhecido como "mapa cor-de-rosa", os lusitanos planejaram interligar suas antigas possessões (Angola e Moçambique) com o intuito de facilitar o comércio e o transporte de mercadorias. Sob ameaça de guerra, o governo inglês persuadiu os mandatários portugueses 
a abandonarem o projeto (PARADA, 2013, p. 32). Deste modo, coube a Portugal consolidar suas posses territoriais para não correr o risco de perdê-las.

Iniciada na década de 1880, a ocupação militar portuguesa completou-se apenas no início do século XX. Moçambique foi a colônia na qual o exército do país europeu atingiu maior abrangência e os soldados "exibiram seus feitos mais ousados" (SERRÃO; OLIVEIRA MARQUES, 2001, p. 476-477). Mas a resistência dos africanos dificultou o empenho lusitano. Via de regra as autoridades nativas foram adversas às mudanças causadas pelo expansionismo europeu e buscaram a manutenção da soberania e independência de seus povos (BOAHEN, 2010, p. 3-4). Mesmo assim, a autoridade portuguesa foi imposta paulatinamente aos autóctones por meio de muitas expedições beligerantes e cobrança de tributos, resultando na ocupação efetiva de Moçambique, Angola e Guiné, atual Guiné-Bissau (UZOIGWE, 2010, p. 23).

Uma vez assegurada a posse destes locais, seguiu-se a prática de dominação característica das primeiras décadas do século que se abria, ou seja, amenizar as iniciativas militares e exercer o controle institucional civil (PARADA, 2013, p. 48). As primeiras feitorias, portos e presídios costeiros foram se transformando em uma ampla rede de "postos administrativos, transporte e comunicações cada vez mais densa" (OLIVEIRA E COSTA; RODRIGUES; OLIVEIRA, 2014, p. 410).

Todavia, pode-se dizer que "Moçambique sofreu de uma instabilidade de governo prejudicial a uma boa administração" (PÉLISSIER, 2000, p. 148). Assim como as demais colônias portuguesas, Moçambique gozou (ao menos oficialmente) de autonomia financeira e descentralização política. A autoridade administrativa ficou concentrada nas mãos do governador, fiscalizado pelo governo da metrópole e assistido pelos conselhos executivo e legislativo (SERRÃO; OLIVEIRA MARQUES, 2001, p. 23-24). Entretanto, durante o regime imperial lusitano, a colônia experimentou trinta e quatro mandatos de governadores gerais, comissários régios e governos provisórios. Já no regime republicano ${ }^{1}$, vivenciou, até o fim de 1918, mais cinco momentos de chefias transitórias. Alongando-se até 1926, registraram-se cinquenta mudanças de comando (PÉLISSIER, 2000, p. 147-148).

Territorialmente, ao menos, a conjuntura foi mais estática. A reforma administrativa promovida por Freire de Andrade, em 1907, já havia distribuído a província em cinco distritos (Lourenço Marques, Inhambane, Quelimane, Tete e Moçambique), cada qual dirigido por um governador. Estabeleceu-se, permanentemente a capital em Lourenço Marques, enquanto os distritos foram subdivididos em conselhos ou circunscrições nas áreas pacificadas e em capitanias-mores nos lugares recentemente conquistados ou considerados inseguros.

\footnotetext{
${ }^{1}$ Após a queda da monarquia portuguesa, inaugurou-se um Governo Provisório republicano que se manteve até 1911, quando ocorreu a promulgação da Constituição. Em 28 de maio de 1926, triunfou uma nova revolução que impôs ao país uma ditadura militar, decretando o fim da I República. Tal período possibilitou a transição para o Estado Novo, constituído oficialmente em 1933. Ver: Proença (2015).
} 
Com perfil multiétnico, a cidade de Lourenço Marques apresentou tendência para a discriminação cultural e social. Ideais segregacionistas embasados na reprodução de hierarquizações raciais metropolitanas motivaram a retirada da população africana das regiões mais centrais e salubres, bem como a realocação da mesma em áreas periféricas e bairros suburbanos (OLIVEIRA E COSTA; RODRIGUES; OLIVEIRA, 2014, p. 441). Neste ínterim, surgiu, em 1908, O Grêmio Africano de Lourenço Marques, organizado por alguns indivíduos da elite local e instituído para a defesa dos interesses da comunidade negra. A associação concentrou vários elementos nativos urbanizados, incluindo a participação de certos brancos (CABAÇO, 2009, p. 124).

A maioria do corpo administrativo da agremiação foi constituída por funcionários públicos ligados ao Porto de Lourenço Marques, Imprensa Nacional, Tribunais, Serviços de Negócios Indígenas, Alfândega, Fazenda, além do setor ferroviário e de obras públicas. Proprietários de terras, tipógrafos, empregados do comércio, amanuenses, oficiais de diligencias e servidores dos correios também foram ocupações corriqueiras dos associados. A promoção do desenvolvimento moral e intelectual dos componentes, auxílio, proteção, difusão de instrução, construção de uma biblioteca e criação de um jornal ou qualquer outro meio de divulgação foram compromissos firmados no estatuto da corporação (NEVES, 1989, p. 145).

Logo nasceu o periódico $O$ Africano, tido como um dos precursores da imprensa no continente. Produzido por "mulatos", dirigiu-se especialmente à população não branca alfabetizada. Redigido em português, possuiu também uma seção grafada em ronga, tendo sido a primeira vez que um jornal moçambicano utilizou uma língua local (ROCHA, 2000, p. 91). Publicado a partir de 1909, começou com emissão semanal, aos sábados, logo passou a ser lançado duas vezes por semana e, no seu auge, três vezes. Durante grande parte de sua história, teve corpo editorial formado por dois irmãos: João Albasini, como diretor, e José Albasini, na função de editor. Com eles também trabalhou o comerciante José dos Santos Rufino, exercendo os cargos de secretário de redação e administrador (PEREIRA, 2013, p. 85).

Importante para a afirmação da incipiente burguesia local, $O$ Africano teve tipografia própria e foi financiado por uma comissão proveniente da Maçonaria, encabeçada pelo capitão Francisco Roque Aguiar e integra da por José Correia da Veiga e o militante socialista Dr. Jaime Ribeiro (ROCHA, 2000, p. 92).

Em 1918, o jornal foi comprado pelo padre Vicente do Sacramento, envolvido em uma sociedade com um judeu estabelecido na África do Sul, chamado Rufe Nylor, responsável pelos negócios lotéricos em Moçambique. Por meio de contrabando, os bilhetes passaram a ser vendidos no país vizinho. Após o regresso de seu sócio para a Europa, o padre Vicente do Sacramento tornou-se diretor do $O$ Africano e incluiu em suas páginas uma seção em língua inglesa na qual publicou os resultados da loteria e as listas de bilhetes premiados, pois tais informações não podiam ser veiculadas oficialmente na África do Sul. Assim, o primeiro 
jornal direcionado aos africanos começou com auxílio da Maçonaria e transformou-se "em veículo de um negócio chorudo montado por uma estranha sociedade: um capitalista judeu e um missionário católico" (ROCHA, 2000, p. 93).

Beneficiando-se do dinheiro arrecadado com a venda do $O$ Africano, os irmãos Albasini assumiram parceria com Estácio Dias, funcionário da Fazenda, e criaram um novo órgão de imprensa, denominado $O$ Brado Africano. Desde o número de estreia, veiculado em 24 de Dezembro de 1918, o jornal ata cou a exploração dos trabalhadores africanos, mostrou-se portavoz da Liga Africana (com sede em Lisboa) e transpareceu a ligação católica de seus criadores (CAPELA, 2009, p. 55). Com frequência semanal, o noticiário apresentou a mesma forma de seu antecessor, tendo sido igualmente escrito em português e ronga, mesmo que o espaço reservado para comunicação na língua local fosse comparativamente menor (ROCHA, 2000, p. 122).

A instalação da redação e tipografia do $O$ Brado Africano foi realizada na sede do Grêmio Africano, entidade que passaria a ser proprietária do jornal. O periódico tornou-se conhecido por colocar em pauta notícias de uma elite mestiça, educada principalmente nas escolas da Maçonaria. A maioria dos componentes desse núcleo social carregou os sobrenomes de seus pais e avós que ali foram governa dores, chefes militares, negociantes de sucesso, etc. Vivendo um tipo de vida burguesa, esses jovens frequentavam os bailes produzidos em bairros ocupados porbrancos e por vezes desatacaram-se na pratica de esportes (ROCHA, 2000, p.123).

A proclamação da República portuguesa proporcionou o desenvolvimento de grupos como esse, que utilizaram as páginas da imprensa como espaço privilegiado de defesa étnica, política e social. A imprensa operária anarco-sindicalista e as publicações africanas nativistas foram exemplos de manifestações dos principais grupos emergentes em Lourenço Marques (SERRÃO; OLIVEIRA MARQUES, 2001, p. 565).

Alguns indicativos numéricos sugerem que o Brado Africano e o Grêmio Africano alcançaram certa representatividade na sociedade moça mbicana. $O$ hebdomadário trabalhou com a perspectiva de possuir aproximadamente 1.200 leitores. Na ocasião da morte de João Albasini, fundador e diretor da associação africana, o periódico estimou que a presença no funeral atingiu a casa dos 5.000 participantes (NEVES, 1989, p. 141).

Do outro lado do oceano também se falou de assuntos coloniais. Todavia, menos do que alguns consideraram ideal. Sob a justificativa de que a população metropolitana carecia de informações sobre o que acontecia em suas terras distantes, foi criada a Agência Geral das Colônias, em 30 de setembro de 1924, na vigência do governo republicano. Tal qual realizado por Estados vizinhos, Portugal fundou um departamento de propaganda focada na divulgação do além-mar. Conferências, congressos, documentários, livros, folhetos, filmes, exposições, mostruários, periódicos, dentre outros veículos de informação, começaram a ser 
criados como instrumentos de propaganda para divulgar e salientar as possibilidades de engrandecimento "desses novos eldorados" (GARCIA, 2011, p. 132).

No decorrer dos anos 1920, a informação colonial passou a "fazer parte de um dos meios de socialização cultural e ideológica" (SERRÃO; OLIVEIRA MARQUES, 2001, p. 71). A imprensa instituída em Portugal já havia chamado para si a responsabilidade de discorrer sobre o universo ultramarino e se demonstrado capaz de intervir no posicionamento dos seus leitores. Os jornais e revistas foram mecanismos importantes para a divulgação e produção da ideia de império em função da difusão em larga escala e da cobertura regular dos acontecimentos coloniais. Com capacidade de influenciar a opinião pública, a imprensa foi primordial para a formulação e disseminação da perspectiva de que as regiões asiáticas, africanas e oceânicas sob influência portuguesa faziam parte da extensão do país. Os periódicos ilustrados também gozaram de destaque na época, lançando gravuras e fotografias que posteriormente apareceram em suportes como livros, álbuns fotográficos e cartões postais (MARTINS, 2012, p. 12).

Como principal publicação da instituição governamental nasceu o Boletim da Agência Geral das Colônias. Produzido em Lisboa, na Rua da Prata, $\mathrm{n}^{0} 34$, o impresso circulou mensalmente em Portugal e nas principais cidades regidas pelo governo português na África até 1969, trazendo notícias a respeito de todas as colônias, com atenção especial para Angola e Moçambique. O periódico disponibilizou dados e opiniões sobre a ação colonizadora, levados a público pelos próprios lusitanos, e foi assinado por vários agentes que compuzeram a Agência Geral das Colônias. A publicação agrupou majoritariamente portugueses nascidos após 1875, provenientes das maiores cidades (Lisboa, Porto e Coimbra)e graduados em Direito pelas Universidades de Coimbra e Lisboa (GARCIA, 2011, p. 597).

Aqueles que se dispuseram a escrever na obra encontraram muito espaço para fazê-lo. Em geral, os artigos inseridos no boletim passaram das vinte páginas. Prova disso é que o material foi organizado em forma de brochura. Os três meses de intervalo entre um número e outro certamente colaboraram para a produção de textos mais longos e analíticos. Economia, legislação, turismo, urbanismo e trabalho foram assuntos sobre os quais muito se falou nas páginas do prospecto. Dada a especificidade apresentada em muitos dos textos, é possível conjecturar que os interlocutores do boletim tiveram origem similar a de seus autores, ou seja, indivíduos que desfrutaram de acesso à educação acadêmica e se mostraram interessados em debate políticos e econômicos a respeito de seus país.

Outras duas coleções de impressão regular também foram produzidas pela mesma agência, sendo elas: O Mundo Português (1934-1947) e Pelo Império (1936-1961). A entidade ainda apoiou a edição de livros e monografias sobre temas coloniais, fazendo desse tipo de trabalho sua especialidade. Paralelo a estas e outras publicações oficiais, despontaram títulos promovidos por iniciativas particulares, com o mesmo caráter divulgador, como os Cadernos 
Coloniais (1920-1960) e a Portugal Colonial (1931-1937), revista assumidamente propagandística das ações imperiais.

Esta última foi propriedade da Emprêsa Portugal Colonial, sediada em Lisboa, na Rua Augusta, $\mathrm{n}^{\circ}$ 229. O Corpo dirigente inicial da revista formou-se pela junção de Henrique Galvão (diretor), J. da Fonseca Ferreira (redator principal) e António Pedro Muralha ${ }^{2}$ (editor). Mesmo não tendo sido oficialmente assumido como redator, Agostinho de Campos ${ }^{3}$ participou dos 72 números da publicação, com a coluna "Carta mensal de Portugal para as Colônias" (CORREIA, 2014, p. 1).

Lançada mensalmente, a Portugal Colonial, Revista de Expansão e Propaganda Colonial contou com a colaboração de membros do governo, militares, ministros, economistas, médicos, professores, empresários e pessoas ligadas aos altos quadros da administração colonial (CORREIA, 2014, p. 2). Como já ressaltado por Martins, a participação de indivíduos em destaque na comunidade portuguesa e o investimento de alguns em empreendimentos voltados à temática colonial indicaram "o comprometimento da sociedade civil com as pretensões do novo regime em incutir na população metropolitana uma cultura imperial" (MARTINS, 2000, p. 153).

Em plena vigência do Estado Novo ${ }^{4}$, foi criado o Secretariado de Propaganda Nacional (SPN), responsável pela divulgação do regime (REVEZ, 2012, p. 13). Tal organismo colocou em prática, nos anos 1930, uma intensa propaganda colonialista com o intúito de arraigar no pensamento da população lusitana a ideia de imprescindibilidade do ultramar para o futuro do páis.

Uma das iniciativas mais eficazes foi a campanha por meio do ensino básico, atingindo diretamente as crianças. Outra das estratégias mais relevantes foi a organização de eventos de grande monta conectados à temática colonial. Destacaram-se, nesse aspecto, a Exposição Colonial do Porto, que reuniu, em 1934, mais de um milhão de visitantes, e a Exposição do Mundo Português, concretizada em 1940, somando aproximadamente três milhões de expectadores (ALEXANDRE, 2013. p. 24).

\footnotetext{
${ }^{2}$ Jornalista e escritor português. Viajou para a África, em1924, e reuniu suas impressões de S. Tomé, Angola e Moçambique no livro Terras da África. Também publicou obras como: Portugal no Brasil, A Alemanha perante a Europa, A Bélgica Heroica, A Proa de Sagres, Cartilha Colonial, História da Colonização dos Portugueses na América do Sul, Álbum Alentejano, Memórias e Roteiro Turístico de Leiria. Ver: Correia (2014, p.1).

${ }^{3}$ Professor universitário, jornalista e escritor português. Exerceu o cargo de diretor-geral da Instrução Pública, entre 1906 e 1910. Colaborou com as revistas Serões (1901 - 1911), Atlântida (1915-1920), Contemporânea (1915-1926) e Ilustração(1926-1975). Também participou dos Anais das Bibliotecas e Arquivos Municipais (1931-1936) e do boletim Mocidade Portuguesa Feminina (1939-1947). Ver Correia (2014, p.1).

${ }^{4}$ Institucionalizado a partir da Constituição de 1933. Como poder concentrado na figura de António de Oliveira Salazar, o regime perdurou até 1974 e caracterizou-se pela censura exercida sobre os cidadãos e negação dos direitos e garantias individuais. Apresentou características semelhantes aos regimes autoritários instituídos por Benito Mussolini, na Itália, e Adolf Hitler, na Alemanha. Ver: Proença (2015).
} 
Henrique Galvão, conforme já mencionado, diretor da Portugal Colonial, foi comissário de exposições como essas por várias vezes. Inclusive, enquanto chefe da Seção Colonial da Esposição do Mundo Português, ele organizou um espaço para que os nativos apresentassem "fielmente" o modo de vida na África (VARGAFTIG, 2014, p. 248). O mesmo também exerceu outras funções de gerência ligadas ao setor de propaganda, atuando nas Feiras de Amostras de Luanda e Lourenço Marques, Exposição Colonial do Porto, Emissora Nacional de Radiodifusão, Exposição Colonial dos Centenários, Comemoraçãoes Centenárias de Guimarães e Cortejo do Mundo (CORREIA, 2014, p. 9).

Muitas dessas atividades foram cumpridas simultaneamente ao trabalho na revista. Contudo, em 1936, Henrique Galvão deixou o periódico para atuar integralmente no ofício de Inspetor Superior de Administração Colonial ${ }^{5}$. Sua trajetória mostrou a capacidade de circular pelos meandros da admnistração governamental e da imprensa propagandística. Até os finais dos anos 40, quando tornou-se um dos principais opositores de Salazar, revelou-se um entusiasmado ativista do império colonial. E isso ficou explícito nas páginas da revista que fundou e dirigiu por seis anos.

Frutos dessa conjuntura entusiástica em relação ao império ultramarino, o Boletim da Agência Geral das Colônias e a Portugal Colonial condensaram elementos da ideologia vigorante entre um núcleo intelectualizado luso interessado na discussão acerca da corrente expansão colonial realizada pelo seu país nas três primeiras décadas do século XX. Por terem sido forjadas em ambiente correlativo e objetivarem ambições semelhantes, as publicações produziram e reproduziram discursos aproximados e adequados a uma linha de raciocínio praticamente contínua. A base para se entender o presente e imaginar o futuro estaria no passado. Portanto, foi preciso falar dele.

\section{A representação dos exploradores pioneiros nos impressos de ambos os lados}

No quinquagésimo aniversário da Sociedade de Geografia de Lisboa ${ }^{6}$, Lourenço Cayolla, professor da Escola Colonial, discursou em sessão solene realizada em 11 de novembro de 1925.

\footnotetext{
${ }^{5}$ Por conta disso, os últimos 10 números da coleção foram publicados sob a direção, administração e edição de António Pedro Muralha.

${ }^{6}$ Impulsionando uma elite urbana irradiada a partir da capital do país, a entidade defendeu o propósito de promover o gosto e a prática da geografia, ou seja, o conhecimento científico dos territórios. Objetivou-se o desenvolvimento de estudos aprofundados e elaboração de registros precisos sobre o meio ambiente das regiões ocupadas pelo governo português, confiando-se na ciência e colonialismo como ferramentas de transformação nacional. Apegados aos ideais de progresso e modernização, esses indivíduos elencaram a exploração das possessões estabelecidas na África como o ponto principal para o engrandecimento e glorificação da nação portuguesa. Ver: Bastos (2013, p. 322).
} 
Praticamente um ano após a ocorrência do evento, os dizeres do convidado foram transcritos no Boletim da Agência Geral das Colônias. Totalizando 29 páginas, o artigo em questão construiu uma retrospectiva da formação imperial portuguesa desde as realizações de D. Henrique, chamado de "o primeiro colonizador". Na sequência, o texto destacou a colonização do território brasileiro, que demandou o "sangue das veias" portuguesas para a edificação de uma "nação nova, suscetível de todos os progressos" (CAYOLLA, 1926, p. 15).

Angola e Moçambique também foram lembrados. Sobre a primeira, comentou-se a respeito da construção de presídios que foram disseminados pela região. Com relação ao segundo, destacou-se a habilidade dos representantes da coroa em erigir processos diferenciados de colonização que souberam aperfeiçoar os contatos com os indígenas e geraram a maximização da ocupação das terras. Por esses e outros motivos, Lourenço Cayolla afirmou categoricamente que os portugueses seriam merecedores da gratidão de todos os demais por representarem o povo que mais havia "trabalhado na causa da civilização universal e mais inteligentemente e, com maior êxito, empregou os seus esforços colonizadores" (CAYOLLA, 1926, p. 19).

Ainda segundo o autor, toda essa volumosa obra pôde ser colocada em prática graças a uma qualidade primordial de seus executores: a capacidade de planejamento, demonstrada a partir das primeiras navegações. Teriam sido os lusos os predecessores a entenderem com maior propriedade as ciências necessárias para as viagens oceânicas modernas e levado tais conhecimentos aos espanhóis, ingleses, holandeses e franceses (CAYOLLA, 1926, p. 12).

Argumentação similar a essa foi exposta em matéria veiculada pela Portugal Colonial. Aluno da Escola Superior Colonial, Nunes dos Santos declarou que "qualquer que tenha sido a causa geradora do movimento expansionista de Portugal, o certo é que o nosso povo não era positivamente, já nesses tempos remotos, aquilo a que se pode chamar um principiante" (SANTOS, 1936, p. 3). Diplomado pela mesma instituição, Alves de Azevedo destacou a paciência e a persistência como elementos fundamentais para a receita portuguesa. Conforme seu ponto de vista,

A colonização portuguesa nunca se preocupou com benefícios imediatos. Foi sempre um empreendimento de largo fôlego. Semelhante critério verdadeiramente imperial no sentido romano da palavra exige tempo; e exige harmonia entre os meios da ação e os recursos nem sempre fáceis de inventar - quer quanto a mão de obra, quer quanto às condições naturais, fatores de que dependem todos os triunfos em todos os aspectos da atividade humana (ALVES DE AZEVEDO, 1936, p. 11). 
Anderson (2008, p. 197) situou o processo de colonização da África e Ásia como parte final do desenvolvimento nacionalista em países europeus estruturados industrialmente. Concordando com ele, Hobsbawm (1988, p. 65) defendeu a tese de que as colônias ganharam relevância na composição do status de grande potência que as algumas nações europeias quiseram chamar para si. Independente do valor econômico, as possessões ultramarinas adquiriram importante representação simbólica nas disputas nacionalistas características do final do século XIX. Cada porção de terra conquistada foi tratada como referencial de força e expressividade política do país que ali fincou sua bandeira.

Pelos comentários expostos nos impressos analisados, pode-se dizer que a mentalidade frisada pelo historiador britânico adentrou o século XX. A constante declaração de que o empenho colonizador português já havia iniciado-se em tempos longínquos e usufruído das forças de muitos habitantes dessa nação, aliada a igualmente insistente alegação de que os outros aprenderam com eles as artimanhas necessárias para chegar a localides afastadas, confabulou um posicionamento autoafirmativo de Portugal em relação aos demais países. Os comentários sobre o Brasil serviram de enredo para endossar o trabalho luso e inspirar maior credibilidade à considerada triunfante trajetória realizada até então. A referência ao "sentido romano" caminhou no mesmo sentido.

A questão colonial subordinou a política externa portuguesa, tendo em vista a necessidade de se encarar contantes ameaças à soberania do Estado instalado nos territórios ultramarinos (MARTINS, 2000, p. 144-145). As teorizações que destacaram longevidade e pioneirismo luistano na edificação de um conglomerado colonial corporificaram uma espécie de resistência ideológica às investidas sofridas. Antes de pensar em furtar as terras lusitanas, Inglaterra, França, Alemanha, Itália e os outros deveriam demonstrar gratidão e respeito a Portugal.

No âmbito interno, o nacionalismo político apresentou uma linha de continuidade ao longo da Monarquia, República e Estado Novo no tocante à ideia de império. A diferenciação em relação as formas de dominações coloniais estrangeiras foram apregoadas por meio de dois quesitos fundamentais: a "herança sagrada" e o "eldorado". Caberia aos portugueses preservarem os territórios recebidos dos antepassados quinhentistas e passarem adiante a concepção de exploração dos recursos naturais e humanos das localidades africanas e asiáticas (GARCIA, 2011, p. 595).

Não obstante, o nacionalismo econômico teve que ser pensado. As feitorias e presídos construídos anteriormente não garantiram penetração e ocupação efetiva dos territórios continentais africanos. Deste modo, desenrolou-se uma reformulação profunda no colonialismo português, direcionando-o para a exploração de recursos agrícolas e minerais das colônias a partir das últimas décadas do século XIX. Para isso, foram necessárias medidas de ocupação de territórios e submissão de populações nativas, o que gerou, naturalmente, guerras prolongadas (SOBRAL, 2012, p. 65). 
As batalhas produzem heróis. Ao menos quando se queira que seja assim. E, tomando como base algumas considerações feitas pelo boletim em relação a Moçambique, o governo metropolitano mostrou interesse em manter a lembrança de combatentes que participaram da apoderação do território. Nesta conjuntura, algumas vitórias marcantes foram exaltadas:

21 de Julho de 1897 é, talvez, a maior data da epopeia portuguesa na África. A figura de Mousinho, o maior soldado português das campanhas da África, está, de tal modo, tão intimamente, tão fortemente, ligado a esta data que é impossível separar uma da outra, que é impossível evocar uma sem que a outra se lhe não associe, desde logo.

Quando se fala, hoje, nas campanhas de Mousinho, na formidável atividade militar do que morreu definindo sua própria morte de cruel enigma, logo acode a mente uma imagem de extraordinário relevo - a carga da cavalaria portuguesa em Macontene (ROCHA, 1934, p. 13).

Na década de 1890, ataques vátuas a Lourenço Marques causaram insegurança entre a população branca europeizada instalada no local. António Enes, antigo ministro da Marinha, foi nomeado Comissário Régio para Moçambique e preparou uma primeira ofensiva contra os nativos, derrotando-os. Alguns meses depois, Mousinho de Albuquerque, lembrado na passagem anterior, substituiu António Enes e deu segmento às campanhas militares, liderando, inclusive, a cavalaria portuguesa no combate de Macontene. Seus sucessores no governo continuaram a submissão de grupos africanos até as vésperas da primeira Grande Guerra (OLIVEIRA MARQUES, 2015, p. 558).

Em razão de suas atuações nos campos de batalha, adjetivações que justificaram as homenagens endereçadas à ilustre figura não faltaram:

Pode-se dizer que Mousinho deu a Portugal Moçambique. Foram as suas vitórias fulminantes sobre o gentio guerreiro e insubmisso que decidiram o futuro da ocupação portuguesa nas terras do interior. Chaimite foi a chave da dominação e submissão das populações negras, que o exemplo de resistência e rebeldia do Gungunhama mantinha em pé de guerra.

Mousinho, porém, não foi apenas o chefe militar - foi, como governador geral da província de Moçambique, o organizador da administração 
política, militar, financeira, econômica e religiosa que havia de ficar para o futuro. Construiu estradas, fundou postos militares e administrativos, aumentou a matéria coletável, protegeu as missões religiosas, teve a preocupação de governar a colônia com as suas próprias receitas (Boletim da Agência Geral das Colônias, 1936, p. 15-16).

Dedicado ao "dia do Mousinho", o artigo foi originalmente publicado no Diário da Manhã, jornal lisbonense. Falar das campanhas desbravadoras e de seus personagens principais consagrou-se como uma das estratégias de propaganda colonial mais praticadas, tendo sido criado um discurso populista em torno das vitórias militares que combinou "a suposta demonstração das capacidades colonizadoras à exaltação nacionalista". Mousinho de Albuquerque foi o exemplo de oficial mais comentado na época e sua fama atingiu maior popularidade especialmente sob efeito da propaganda lançada no Estado Novo. Teixeira Pinto, Artur de Paiva, Alves Roçadas, Pereira de Eça, Paiva Couceiro, Freire de Andrade e tenente Aragão foram outros nomes repercutidos na imprensa (SERRÃO; OLIVEIRA MARQUES, 2001, p. 65).

Comentários sobre individualidades como estas engendraram uma "prova" de que o Império português existia há séculos e foi construído por uma elite que sempre se interessou pela descoberta, preservação e manutenção de todo patrimônio conquistado desde os tempos dos primeiros navegantes e monarcas desbravadores. Além disso, as narrativas contemporâneas sobre atos de defesa militar (séculos XIX e XX) passaram a ser dadas como testemunhos de que os territórios eram patrimônios conquistados pelos antepassados e deveriam, portanto, serem preservados e transmitidos às gerações vindouras (GARCIA, 2011, p. 597).

O aumento das pressões sociais de administrar territórios ultramarinos recentes e eleitorados nacionais cada vez maiores fez com que as elites governamentais europeias se deparassem com a necessidade de emanar seu poder do passado, da tradição, da antiguidade (SAID, 2011, p. 52). Parte desse conjunto, Portugal teve a questão colonial conectada a sua política. O projeto colonial foi entrelaçado aos temas dominantes do nacionalismo lusitano e as terras ocupadas no além-mar foram caracterizadas como demonstração do prestígio do passado e garantia da identidade e sobrevivência do país (ALEXANDRE, 2013, p. 27).

A partir de 1933, O Estado Novo criou mecanismos para intervir diretamente na vida das pessoas. No campo cultural, foi organizada uma abordagem que pretendia estabelecer ligação e aceitação de alguns aspectos do modernismo com a exaltação de valores nacionalistas, patrióticos e populares, o que ficou conhecido como "política do espírito". Criada e defendida por António Ferro, chefe do Secretariado de Propaganda Nacional, essa política objetivou que todas as produções artísticas e literárias obedecessem às normas ditadas pelo regime e 
afirmassem os padrões estéticos de feição nacionalista e historicista". Tais determina ções atingiram o rádio, teatro, cinema, literatura, artes plásticas, músicas, dentre outras esferas do campo cultural, e o crivo da censura passou a ponderar o que poderia ser exposto (PROENÇA, 2015, p. 674). Obviamente a imprensa também foi afetada e aquilo que já era feito com maior liberdade durante a república foi esquematizado sistematicamente e transformado em compromisso.

Temas importantes do nacionalismo republicano foram retomados e aprofundados. A considerada "missão histórica" colonizadora e evangelizadora, constituinte primordial da "essência orgânica da Nação portuguesa", fundamentou e legitimou a ocupação dos domínios ultramarinos. A defesa desse direito e a integridade do patrimônio colonial foram ratificadas como condições inseparáveis da proteção da própria independência nacional portuguesa. A centralização político-econômica do Estado Novo foi apontada como requisito para a salvação e expansão do território português e o resgate das tradições e glórias do passado foi eleito como fio condutor da "restauração" de que necessitava o império. Colônias, nação e regime político fundiram-se numa "construção mítica" (ROSAS, 2001, p. 255).

Os veículos de comunicação existentes durante o Estado Novo contribuíram para salientar a mentalidade imperial junto ao povo lusitano. Propagaram incessantemente a perspectiva de que, ao contrário das demais nações europeias, Portugal possuía um império oriundo de tempos antigos e sua obra não era resultado acidental das disputas políticas características dos finais do século XIX. Notabilizaram, igualmente, a alegada capacidade desbravadora dos colonos portugueses, indiferentes aos perigos e capazes de lidar com os indígenas (ALEXANDRE, 2013, p. 188).

Para os idealizadores da doutrina estabelecida pelo governo salazarista era necessário reavivar o sentido colonizador dos portugueses, reascender a chama da conquista na alma dessas pessoas. Mais relevante que o poder material seria o "poder incorpóreo e espiritual dos homens empenhados nessa tarefa de construir e transformar novos lugares e novos mundos, à imagem e semelhança da cultura colonizadora que teria importância a partir da sua apropriação e dominação" (GARCIA, 2011, p. 87-88).

Parte dessa engenharia ideológica, o Boletim da Agência Geral das Colônias e a Portugal Colonial direcionaram acentuadamente suas editorações para a rememoração dos acontecimentos e heróis do passado. Insistentemente esses temas foram apresentados pelos materiais, demonstrando a influência política sofrida por eles e a intencionalidade ou necessidade de realçar o pensamento vigente junto à sociedade. Curiosamente, $O$ Brado Africano também apresentou inclinação aos preceitos nacionalistas e historicistas em certas ocasiões. Ainda na década de 1920, um colaborador do jornal afirmou ter vivido uma experiência metafísica que envolveu o combatente tão condecorado pelas publicações portuguesas. Entusiasmado, ele escreveu o seguinte relato: 
Eram duas horas da madrugada do dia 22 do corrente em que fui acordado pelo alarme da campainha do despertador. Levantei-me para a parar, mas pouco tempo depois, a campainha voltou a tocar quando pegava no sono!

Ao abrir os olhos aligeirou-se me que via na minha frente, muito firme, Mousinho de Albuquerque!...

Resolvi entrevista-lo e perguntei-lhe:

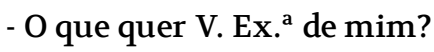

- Ele, com a voz muito suave, disse-me:

Venho Agradecer-te as palavras que disseste a meu respeito no "Brado Africano", sobre o ataque que me fez "O Oriente".

- Nada tem que me agradecer, não fiz mais do que o dever em defender a sua memória (FIGUEIREDO, 1922, p. 2).

O diálogo continuou com uma solicitação de Mousinho de Albuquerque para que seu interlocutor denunciasse a "invasão" de indianos na administração da colônia. Chama a atenção fato de que o periódico exaltou uma figura intrinsicamente ligada à submissão dos povos nascidos na região. Em outro volume do periódico, Manuel Caraco (1934, p. 1), de procedência não declarada, assinou um artigo no qual elogiou a "pátria" e "uma galeria imensa de nobres portugueses" que trabalharam a favor da conquista e ocupação de terras brasileiras e africanas. Dez anos antes, em 1924, a participação em festas cívicas foi tratada como um dever de todos e foi cobrada nobilitação a um personagem das primeiras navegações:

É grato recordar os feitos de um herói, como é dever tributar a esse herói o preito da nossa homenagem.

Vasco da Gama, o glorioso navegador, descobrindo o caminho marítimo das Índias, conquistou uma grande glória para Portugal. Esta glória, porém, que necessita ser reativada, através de todos os tempos, por parte de todos os portugueses, seguindo os exemplos de Fé e de Patriotismo 
que nos legou Vasco da Gama, começou sendo empanada a breve trecho (CARACO, 1924, p. 1).

Mouillaud (2012, p. 102) expôs que o título de um jornal forma uma espécie de "envelope" que passa a conter pressuposições e expectativas de enunciados por parte dos leitores. Seguindo esta lógica e considerando-se o contexto colonial, é plausível imaginar sumariamente que $O$ Brado Africano carregaria consigo um ar de ruptura com as tradições metropolitanas. Como explicar, então, que a postura do periódico quanto aos heróis e grandes feitos portugueses foi idêntica à adotada pelos veículos de propaganda produzidos pelos colonizadores? Indubitavelmente a decifração dessa interrogação passa pelo "Estatuto do Assimilado".

Criado na primeira república, o documento concretizou a distinção jurídica entre "indígena" e não "indígena" por meio de um alvará entregue pela administração portugue sa àquele capaz de provar que havia assumido comportamento social e cívico de cunho europeu. O interessado deveria comprovar que usufruía de considerável grau de educação, demonstrando fluência oral e escrita na língua portuguesa, fazer parte de um casamen to monogâmico, possuir ao menos um traje ocidental, declarar renda proveniente de propriedades ou negócios comerciais e, principalmente, deixar claro que abandonara as tradições culturais autóctones (SERRÃO; OLIVEIRA MARQUES, 2001, p. 527-528).

Na opinião de Davidson, Isaacman e Pélissier (2010, p. 817), a política de assimilação formou um definitivo marco de distinção do regime colonial português ao tentar conquistar a incipiente burguesia africana com um "verniz" da cultura europeia e parecer livrá -la dos abusos coloniais mais explícitos. Ao pé da letra, todos poderiam galgar o status de "assimilado", todavia as precárias condições de educação e trabalho impediram cerca de 99\% da população de Moçambique e Angola de conquistarem o título de cidadão.

Esperava-se dos considerados "assimilados" maior sintonia com os valores da cultura lusa e a crença na ilusão de que a sociedade colonial oferecia mobilidade social. Formada por poucos, essa pequena elite de africanos teria o papel de servir aos interesses coloniais e "constituir-se intermediários entre dominador e dominado" (CABAÇO, 2009, p. 119). Exigindo a prática de costumes ocidentais, a política de assimilação buscou estabelecer o rompimento com os valores locais e corporificou a "missão civilizadora" (CABAÇO, 2009, p. 115).

A consonância com as ideologias imperialistas lusitanas poderia render alguns frutos para os africanos dentro da própria sistemática criada pelos europeus. Em mais uma oportunidade de expor seus pensamentos, Manuel Caraco (1934, p. 1) argumentou que: 
Nunca como até hoje os nossos homens cultos reconheceram a necessidade de unir à Pátria o nosso Vasto Império Ultramarino. Para que essa união faça- se firme em princípio consagrado ao bem comum, necessário se torna ensinar a todo o português, que temos em África, muita gente que deseja dar ingresso em nossos corações. Enquanto persistir a ignorância que leva o nosso povo a ver em África unicamente selvagens, não poderemos avançar um passo no caminho indicado à boa comunhão. É preciso, é necessário demonstrar a todo o português, que são os nossos domínios ultramarinos a coroa de brilhantes da Pátria portuguesa. Perder esses domínios seria perder o nosso melhor tesouro. Arrancar ao povo português a ideia parva de lidar em África com gente inculta e selvagem é dever que só cabe a quem conheceu e conhece de perto o trato do povo africano.

$[\ldots]$

Quanto mais culto for o preto, tanto mais o devemos aproximar da nossa convivência. Há os que, pela educação e cultura espiritual, deveriam conhecer Portugal com os seus encantos, com as suas maravilhas. Demonstrar ou ensinar ao povo português o valor desta raça robusta e forte, é dever daqueles que desejam intensificar, adentro do Império Luso Africano - a sagrada União.

A percepção de "império" no decorrer do Estado Novo inferiu uma ideia de "alargamento" e extensão do território metropolitano para os domínios estabelecidos no ultramar (GARCIA, 2011, p. 87). A "sagrada união" apontada por Manuel Caraco formar-se-ia pelo relacionamento entre os portugueses e os habitantes das localidades tomadas pelos ibéricos. Neste sentido, aquele que assinou o artigo defendeu que a aproximação entre as duas partes necessitava da elaboração de novas perspectivas lusitanas a respeito dos africanos. Despontou, por conseguinte, a caracterização do assimilado, "culto" e "educado", capaz de romper com os estigmas e viabilizar a harmonização entre os grupos. Foi composta, assim, uma clara e objetiva significação a respeito deste considerado seleto grupo de negros e atribuído a tais indivíduos um papel preponderante na sociedade colonial, ao menos no que diz respeito ao campo discursivo.

É certo que colocações tão determinantes não foram exteriorizadas pelos principais organizadores do $O$ Brado Africano. Do mesmo modo, também é conveniente afirmar que dificilmente algum texto tenha sido veiculado sem a anuência do corpo editorial da folha. Genericamente, os africanos envolvidos com o jornal desfrutaram de condições suficientes para atender a os preceitos básicos à obtenção do título de "assimilado" e não se posicionaram 
publicamente contra as ideias lançadas por Manuel Caraco e companhia. Salvo engano, portanto, é admissível presumir que tais enunciados os tenham representado.

O funcionamento prático da assimilação reforça esta hipótese. A posição de assimilado não simbolizou necessariamente a integração do indígena à comunidade portuguesa instalada em Moçambique. Mesmo condecorado com o reconhecimento jurídico da cidadania lusa, no plano social ele costumeiramente permaneceu subalternizado, vagando entre uma "casta inferior" dos colonos e uma "casta superior" no mundo dos nativos (CABAÇO, 2009, p. 119). Neste sentido, o protagonismo negro na causa integracionista defendida por Manuel Caraco veio a calhar, pois deu notória magnitude ao grupo e rebateu a desconfiança atribuída a ele.

Como já lembrado por Zicman (1981, p. 90), as informações apresentadas pela imprensa não são escolhas aleatórias. Pelo contrário, demonstram atitudes "próprias" de cada jornal, organizado de acordo com seu "filtro" acerca do que deve ou não ser noticiado. Comparativamente a outros assuntos levantados constantemente pelo semanário, as memórias sobre os portugueses antepassados não é temática das mais primordiais. Mas é preciso lembrar que periódico levou a questão até os seus leitores. E, se o fez, foi com algum propósito definido.

Fundamentando-se na concepção desenvolvida por Capelato e Prado (1980, p. 19) e, portanto, tomando-se os impressos como capazes de engendrar intencionalidades e interferir na ordem social, é plausível questionar o possível interesse dos redatores em inculcar o saudosismo em relação ao passado lusitano no imaginário dos indígenas, teoricamente agentes com os quais os assimilados fariam intermediação. A produção de matérias numa das principais línguas locais seria uma ferramenta interessante para a realização desse intento. Contudo, a pouca quantidade de vezes em que o jornal pronunciou-se sobre o tópico e a ausência de deliberações mais enérgicas e diretivas por parte dos autores permitem imaginar, ao menos, que esse não foi um dos principais objetivos projetados pelo hebdomadário.

A rememoração de um passado que desprivilegiou a memória dos povos nascidos em Moçambique antes da chegada portuguesa pareceu ter uma finalidade ligada a o tempo presente. Ela pode ter representado uma tentativa de demarcação de posição por parte dos representantes negros do jornal. Ao compactuar com a história dos colonizadores, os africanos em questão externaram uma suposta afinidade com os portugueses, buscando eventualmente estabelecer uma relação de pertencimento a esse grupo e, porventura, tirar algum proveito disso.

Visto por essa ótica, os escritos ufanistas contidos no jornal tornaram-se uma espécie de autoafirmação de indivíduos que se colocaram próximos de uma identidade portuguesa e, de certo modo, afastaram-se da ligação com os demais africanos "incultos". A referência à tradição ibérica substanciou o surgimento de um grupo social que afirmou defender os 
interesses dos originários de Moçambique, mas associou-se ocasionalmente à ideologia utilizada para afiançar o imperialismo. Por mais contraditório que pareça, configurou-se aí uma adequação espontânea ou premeditada ao sistema metropolitano implantado. .

Conforme as observações de Le Goff (1990, p. 288), o documento histórico é, na verdade, fruto da sociedade que o fabricou e das relações de forças detentoras de poder atuantes nessa coletividade. A aceitação de um discurso comum entre os setores metropolitanos intelectualizados por parte dos nativos moçambicanos ligados ao $O$ Brado Africano pode ter significado tanto a internalização propriamente dita dos ideais proferidos, quanto o artifício intencional de aproximar-se do centro de poder com intuito de angariar representatividade social e respeito para si e, consequentemente, para o jornal pelo qual se expressaram.

\section{Considerações finais}

As reflexões sobre o imperialismo europeu no continente africano exigem indagações sobre os aspectos ideológicos ligados ao tema. A construção e manutenção de domínios distantes não se sustentaram sem o auxílio de ferramentas que objetivaram atingir o âmago de homens e mulheres comandados por Estados autointitulados colonizadores. Fazer crer na imprescindibilidade e sucesso dos planos lançados por cada governo metropolitano transformou-se em matéria vital para a longevidade das colônias.

Um dos principais meios de comunicação da época, a imprensa viu-se forçada a discutir o que disse respeito ao além-mar. Ao aprofundar-se minimamente nas particularidades dos títulos comentados, pôde-se notar que a conjuntura política do início do século XX cobrou isso dos periódicos em questão. Assim como tantos outros, eles colocaram no papel as manifestações de seus autores sobre o mundo colonial erigido por Portugal e levaram opiniões particulares e expectativas. As relações com o poder estabelecido inevitavelmente também ganharam espaço.

A rememoração do passado colonizador lusitano atingiu caráter legitimador. Para os impressos financiados pelo governo ou diretamente influenciado por seus ideais, a ênfase na primazia das grandes navegações e a sequência de ações colonizadoras no desenrolar da história portuguesa sustentou a ideia de continuidade de um império erigido ao longo de séculos e merecedor de respeito por não ser uma aventura brevemente iniciada na Conferência de Berlim. Para o jornal organizado por nativos moçambicanos, significou uma moção de aproximação com o núcleo mais prestigiado na estrutura social, o que não quer dizer, necessariamente, subserviência. 


\section{Referências}

ALEXANDRE, Valentim. O Império Africano (Séculos XIX - XX) - As linhas gerais. In: ALEXANDRE, Valentim (coord.) O Império Africano: séculos XIX e XX. Lisboa: Edições Colibri, 2013. p 11-28.

ALVES DE AZEVEDO. Consciência Imperial. Portugal Colonial, Revista de expansão e Propaganda Colonial. Lisboa, n. 61, p.11- 22. 1936.

ANDERSON, Benedict R. Comunidades Imaginadas: reflexões sobre a origem e a difusão do nacionalismo. Tradução de Denise Bottman. São Paulo: Companhia das Letras, 2008.

BASTOS, Cristina. Das viagens científicas aos manuais de colonos: a sociedade de Geografia e o conhecimento da África. In: CENTRO DE ESTUDOS AFRICANOS DA UNIVERSIDADE DO PORTO (Coord.). O colonialismo português: novos rumos da historiografia dos PALOP. Lisboa: Edições Húmus, 2013. p. 321-346.

BOAHEN, Albert Adu. A África diante do desafio colonial. In: . História Geral da África: África sob dominação colonial, 1880-1935. 2. ed. rev. Brasília: UNESCO, 2010. p.1-41.

BRAGA, José Luiz. Questões Metodológicas na leitura de um jornal.In: MOUILLAUD, Maurice; PORTO, Sérgio Dayrell (Org.). O jornal: da forma ao sentido. 3. ed. Brasília: Editora Universidade de Brasília, 2012. p.289-306.

CABAÇO, José Luis. Moçambique: identidade, colonialismo e libertação. São Paulo: Editora UNESP, 2009.

CAPELA, José. O Movimento Operário em Lourenço Marques (1898-1927). Porto: Centro de Estudos Africanos da Universidade do Porto, 2009.

CAPELATO, Maria Helena; PRADO, Maria Lígia. O Bravo Matutino: imprensa e ideologia no jornal “O Estado de São Paulo". São Paulo: Editora Alfa-Ômega, 1980.

CARACO, Manuel. A Pátria Portuguesa. O Brado Africano, Lourenço Marques, n.97 p.1-2. 1934 . Portugal e seus domínios. O Brado Africano, Lourenço Marques, n. 94, p.1, 1924.

CAYOLLA, Lourenço. A Obra da Colonização Portuguesa. Boletim da Agência Geral das Colônias, Lisboa, n. 7, p.15-21, 1926. 
CORREIA, Rita. Carta mensal de Portugal para as Colônias. 2014. Disponível em: $<$ http://hemerotecadigital.cm-lisboa.pt/FichasHistoricas/PortugalColonial.pdf $>$. Acesso em: 15 ago. 2016.

DAVIDSON, Basil; ISAACMAN, Allen F.; PÉLISSIER, René. Política e nacionalismo nas Áfricas central e meridional, 1919 - 1935. In: BOAHEN, Albert Adu. História Geral da África: África sob dominação colonial, 1880-1935. 2. ed. rev. Brasília: UNESCO, 2010. p.814-935.

DOS SANTOS, Nunes. A obra colonial portuguesa: métodos. Portugal Colonial, Revista de expansão e Propaganda Colonial, Lisboa, n. 58, p.3-7. 1936.

FIGUEIREDO, Ruy. Um sonho com Mousinho d'Albuquerque. O Brado Africano, Lourenço Marques, n. 2, p.2, 1922

GARCIA, José Luís Lima. Ideologia e Propaganda Colonial no Estado Novo: da Agência Geral das Colônias à Agência Geral do Ultramar, 1924-1974. 2011. Tese (Doutorado em História Contemporânea) - Faculdade de Letras da Universidade de Coimbra. Lisboa, 2011.

HERNANDEZ, Leila M. G. L. A África na sala de aula: visita à história contemporânea. 2. ed. rev. São Paulo: Selo Negro, 2008.

HOBSBAWM, Eric J. A era dos impérios (1875-1914). Tradução de Sieni Maria Campos e Yolanda Steidel de Toledo. Revisão técnica de Maria Celia Paoli. 7. ed. Rio de Janeiro: Paz e Terra, 1988.

LE GOFF, Jacques. História e Memória. Tradução de Bernardo Leitão. Campinas: Editora da UNICAMP, 1990.

MARTINS, Fernando. A questão colonial na política externa portuguesa. In; ALEXANDRE, Valentin (Coord.). O Império Africano: séculos XIX e XX. Lisboa: Edições Colibri, 2000. p. 144175.

MARTINS, Leonor Pires. O império de papel: imagens do colonialismo português na imprensa periódica ilustrada (1875-1949). Lisboa: Edições 70, 2012.

MOUILLAUD, Maurice. O nome do jornal. In: MOUILLAUD, Maurice; PORTO, Sérgio Dayrell (Org.). O jornal: da forma ao sentido. 3. ed. Brasília: Editora da Universidade de Brasília, 2012. p.101-113.

MOUSINHO deu a Portugal Moçambique. Boletim da Agência Geral das Colônias. Lisboa, n. 128, p.15-16, 1936.

NEVES, Olga Maria Lopes Serrão Iglésias. Em defesa da causa africana: Intervenção do Grêmio Africano na sociedade de Lourenço Marques. 1908-1938. 1989. Dissertação (Mestrado em História sec. XIX e sec. XX) - Universidade Nova de Lisboa, Lisboa, 1989. 
OLIVEIRA E COSTA, João Paulo; RODRIGUES, José Damião; OLIVEIRA, Pedro Aires. História da expansão e do império português. Lisboa: A Esfera dos Livros, 2014.

OLIVEIRA MARQUES, A. H. de. Breve História de Portugal. 9. ed. Lisboa: Editorial Presença, 2015.

PARADA, Maurício. História da África contemporânea. Rio de Janeiro:Ed. PUC-Rio: Pallas, 2013.

PÉLISSIER, Réne. História de Moçambique: formação e oposição (1854-1918). Tradução de Manoel Ruas. 3. ed. Editorial Estampa: Lisboa, 2000. v.1.

PEREIRA, Mateus Serva. Anúncios e comunicados: 80 réis por linha: propaganda e cotidiano nas páginas de O Africano (1909-1919). In: RIBEIRO, Alexandre Vieira; GEBARA, Alexsander Lemos de Almeida. Estudos africanos: múltiplas abordagens. Niterói: Editora da Universidade Federal Fluminense, 2013.

PROENÇA, Maria Cândida. Uma História Concisa de Portugal. Lisboa:Temas e Debates - Círculo de Leitores, 2015.

REVEZ, Natasha Finz Machado Paulino. Os álbuns Portugal 1934 e Portugal 1940: dois retratos do país no Estado Novo. 2012. Dissertação (Mestrado em História da Arte) - Faculdade de Ciências Sociais e Humanas da Universidade Nova de Lisboa. Lisboa, 2012.

ROCHA, Idílio. A Imprensa de Moçambique: história e catálogo (1854-1975) Lisboa: Edição Livros do Brasil-Lisboa, 2000. (Coleção Mundo Ibérico).

ROCHA, Hugo. Há 37 anos... O combate de Macontene, página de epopeia. Portugal Colonial, Revista de expansão e Propaganda Colonial. Lisboa, n. 13, p.1-2, 1934.

ROSAS, Fernando. História de Portugal: o Estado Novo (1926-1974). Lisboa: Editorial Estampa, 2001.

SAID, Edward W. Cultura e Imperialismo. Tradução de Denise Bottman. São Paulo: Companhia de Bolso, 2011.

SERRÃO, Joel; OLIVEIRA MARQUES, A. H. Nova História da expansão portuguesa: O Império Africano (1890-1930). Lisboa: Editorial Estampa, 2001.

SOBRAL, José Manuel. Portugal, Portugueses: uma identidade nacional. Lisboa: Fundação Francisco Manuel dos Santos, 2012.

UZOIGWE, Godfrey N. Partilha europeia e conquista da África: apanhado geral. In: BOAHEN, Albert Adu. História Geral da África: África sob dominação colonial, 1880-1935. 2. ed. rev. Brasília: UNESCO, 2010. p.33-67. 


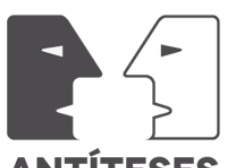

ANTÍTESES

VARGAFTIG, Nadia. Para Ver, para vender: o papel da imagem fotográfica nas exposições coloniais portuguesas (1929-1940). In: VICENTE, Filipa Lowndes (Org). O Império da Visão: fotografia no contexto colonial português (1860-1960). Lisboa: Edições 70, 2014. p. 343-355.

ZICMAN, Renée Barata. História através da imprensa: algumas considerações metodológicas. Projeto História. São Paulo. n. 4, p.89-102, 1981.

Recebido em 02/12/2016

Aprovado em 26/06/2017 